\title{
Phosphotransferase-mediated Regulation of Carbohydrate Utilization in Escherichia coli K12: the Nature of the iex (crr) and gsr (tgs) Mutations
}

\author{
By F. PARRA, M. C. JONES-MORTIMER* AND H. L. KORNBERG \\ Department of Biochemistry, University of Cambridge, Tennis Court Road, Cambridge, \\ $C B 21 Q W, U . K$.
}

(Received 25 May 1982)

\begin{abstract}
Mutants of Escherichia coli $\mathrm{K} 12$ defective in the gene iex (crr) no longer utilize glucose or $\mathrm{N}$ acetylglucosamine in preference to lactose, but competition between either of these sugars and another that also enters by a phosphotransferase (PT) mechanism is not affected. In this they differ from gsr (tgs) mutants. In gsr mutants, glucose does not exclude any other sugar, though $N$-acetylglucosamine still does so. In $g s r$ mutants that are also $p t s M$ the phosphoenolpyruvatedependent phosphorylation of glucose or methyl $\alpha$-glucoside is reduced by $90 \%: \mathrm{N}$ acetylglucosamine phosphorylation is not affected. The iex mutation does not affect the phosphorylation of either of these compounds. The wild-type alleles $i e x^{+}$and $g s r^{+}$are dominant in $\lambda$ heterozygotes. Glucose inhibits the lactose permease of wild-type cells, but only when the permease is present in low amounts. The inhibition is also relieved (1) by induction of another transport system that is subject to regulation by the iex system or (2) by an iex mutation. We suggest that the iex gene specifies a protein that, in cells transporting certain sugars by a PT mechanism, acts to inhibit active transport systems. The protein is present in limiting concentration in the cell, sufficient only to inhibit the basal, uninduced, level of the active transport systems. In consequence the inducer (or its precursor) may be excluded from the cell and induction thus prevented.
\end{abstract}

\section{INTRODUCTION}

Certain hexoses, hexitols and amino-hexoses ('PT sugars') are taken up by Escherichia coli via a phosphotransferase (PT) mechanism (Kundig et al., 1964). In this, the phosphate group of phosphoenolpyruvate is transferred by an enzyme (Enzyme I, specified by the gene ptsI) to (usually) a small histidine-containing protein ( $\mathrm{HPr}$, specified by $p t s H)$; however, a different and larger carrier, designated Fpr, is also involved in the uptake of fructose (Waygood, 1980). The phosphorylated carriers P-HPr or P-Fpr subsequently transfer that phosphate, either directly or via further carriers loosely associated with the inner membrane and generically termed 'factors III' (Roseman, 1972) to enzymes II that are firmly embedded in this membrane. These enzymes II effect the transfer of the phosphate group to specific sugars with concomitant translocation of the sugars into the cell.

Although this overall sequence of events adequately describes the phosphoenolpyruvatedependent uptake of relevant carbohydrates, it is not sufficient to explain two observations that imply other functions of the phosphotransferase system.

(1) Growth of $E$. coli on sugars that are taken up via 'active transport' processes ('non-PT sugars'), occurs only after prolonged lag if the organisms lack either functional enzyme I (Gershanovitch et al., 1967; Wang et al., 1970) or HPr (Gershanovitch et al., 1977). When lactose was the substrate, this lag could be shortened by the provision of cAMP or by addition of the non-catabolizable inducer isopropyl $\beta$-D-thiogalactoside (IPTG) (Pastan \& Perlman, 1969). Similarly, the addition of cAMP to cultures of mutants lacking enzyme I activity enables them to grow on glycerol (Berman et al., 1970) and on many other non-PT substrates (Watts, 1979). 
(2) Glucose, which is taken up via the phosphotransferase system predominantly through an enzyme II (specified by ptsG) that is associated with a glucose-specific 'factor IIIGlc' (reviewed by Postma \& Roseman, 1976), also exerts profound effects on the utilization of other sugars. It represses the synthesis of inducible enzymes required for the catabolism of those other sugars, and it inhibits the continued utilization of other sugars even though the transport systems and enzymes required for the utilization of those other sugars were fully active prior to the addition of glucose. The former effect, catabolite repression (Magasanik, 1961) affects the differential synthesis of cellular proteins; the latter effect, catabolite inhibition (McGinnis \& Paigen, 1969, 1973), affects the activity of specific transport systems (reviewed by Kornberg et al., 1980).

Two different mutations have been found that alter the expression of these regulatory functions of the phosphotransferase system. Mutants of $E$. coli altered in a function that was originally termed $\mathrm{crr}$ but, for reasons discussed below, is now termed iex, were selected as organisms able readily to utilize non-PT sugars despite absence of enzyme I activity (JonesMortimer \& Kornberg, 1974). Mutants of E. coli altered in a function originally termed $t g s$ but now termed $g s r$ were selected as or ganisms that continued to utilize PT sugars despite the presence of the (usually toxic) glucose analogue 5-thioglucose, but that were not devoid of PtsG function (Kornberg \& Watts, 1978). Both mutations map close to $p t s H$ and $p t s I$, though preliminary analysis indicated that they were located on opposite sides of these genes (Kornberg \& Watts, 1979; Kornberg et al., 1980).

In retrospect, it is clear that the original designation of the former type of $E$. coli mutant as ' $c r r$ ' was unfortunate, and has given rise to much confusion in the literature. Jones-Mortimer \& Kornberg (1974) adopted this notation because their $E$. coli mutants were apparently closely similar to, or identical with, crr mutants of Salmonella typhimurium that had been previously described by Saier \& Roseman (1972). We show in this paper that the 'crr' mutation in E. coli is quite different in its effects from that designated crr in $S$. typhimurium, and that it is the lesion originally termed tgs in $E$. coli that is closely similar to 'crr' in $S$. typhimurium. We also show that the 'crr' mutation in $E$. coli is concerned with inducer exclusion whereas 'tgs' is specific to substrates of the PtsG system; the accompanying paper (Britton et al., 1983) demonstrates that these two genes are located on opposite sites of ptsI on the $E$. coli genome, which emphasizes that they must be distinct genes. For these reasons, we now adopt the notation 'iex' for the gene specifying inducer exclusion, and 'gsr' for that specifying glucose-specific repression.

\section{METHODS}

The minimal medium was that of Ashworth \& Kornberg (1966). Bacteriophage techniques are described in the accompanying paper (Britton et al. 1983). The Escherichia coli strains used are listed in Table 1. The relative utilization of carbon sources from a mixture was measured as described by Amaral \& Kornberg (1975); adenylate cyclase was assayed by the method of Salomon et al. (1974) and the phosphotransferase activity of toluene-treated cells was measured by the procedure of Kornberg \& Reeves (1972a). $\beta$-Galactoside permease was measured by determining the rate of $o$-nitrophenol formation when intact cells were incubated in the presence of $o$-nitrophenyl$\beta$-D-galactoside (ONPG) in $50 \mathrm{mM}$-sodium phosphate buffer, $\mathrm{pH} 7 \cdot 2$, containing $50 \mu \mathrm{g}$ chloramphenicol $\mathrm{ml}^{-1}$. The process of hydrolysis in vivo is proportional to the transport rate (Rickenberg et al., 1956).

\section{RESULTS}

\section{The phenotypes of iex and gsr mutations}

Mutants affected in the genes iex and gsr differ from wild-type organisms and from each other in several important respects.

Utilization of carbon sources for growth. Since glucose is known to enter $E$. coli both via a membrane-associated uptake system specified by $p t s G$ and to a lesser extent also via one specified by ptsM (Kornberg \& Jones-Mortimer, 1975; Curtis \& Epstein, 1975), and since fructose can also be taken up by the latter system (Kornberg \& Jones-Mortimer, 1975) it is advisable to study the effects of the iex and gsr mutations in organisms that are $p t s M$. The rates of growth of three such strains on a variety of carbon sources are shown in Table 2 . It is evident that in the presence of functioning enzyme I (i.e. at $30^{\circ} \mathrm{C}$ in these $p t s I^{\text {ts }}$ organisms), the iex 
Table 1. Escherichia coli strains used

The $\lambda$ phage are described by Britton et al. (1983).

\begin{tabular}{|c|c|c|c|c|c|c|c|}
\hline \multicolumn{2}{|l|}{ Strain } & \multicolumn{6}{|c|}{ Genotype } \\
\hline FP6 & iex & $u m g C$ & $p t s I^{\text {ts }}$ & met $B$ & & & \\
\hline FP 19 & iex & umgC & $p t s I^{t s}$ & met $B$ & $p t s H(\lambda p t s H$ & $\left.{ }^{+} i e x^{+}\right)$ & \\
\hline FP20 & iex & umgC & $p t s I^{\mathrm{ts}}$ & met $B$ & ilvA : : Tn5 & & \\
\hline FP31 & & umgC & $p t s I^{\text {ts }}$ & met $B$ & ilvA :: Tn 5 & & \\
\hline FP34 & & umgC & $p t s I^{\text {ts }}$ & metB & ilvA : : $\operatorname{Tn} 5$ & lacI & \\
\hline HK 724 & & umgC & $p t s M$ & $p t s I^{\text {ts }}$ & argH thr & leu & $\operatorname{cys} A$ \\
\hline HK 656 & $g s r$ & $u m g C$ & $p t s M$ & $p t s I^{\text {ts }}$ & $\arg H$ thr & leu & \\
\hline HK 727 & iex & umgC & $p t s M$ & $p t s I^{\text {ts }}$ & $\arg H$ thr & leu & \\
\hline JM1781 & $g s r$ & umgC & $t h r$ & leu & cys $A$ & & \\
\hline JM 1784 & & $u m g C$ & $t h r$ & leu & & & \\
\hline JM1785 & gsr & umgC & $t h r$ & leu & cysA ( $\operatorname{ccys} A$ & $\left.{ }^{+} g s r^{+}\right)$ & \\
\hline
\end{tabular}

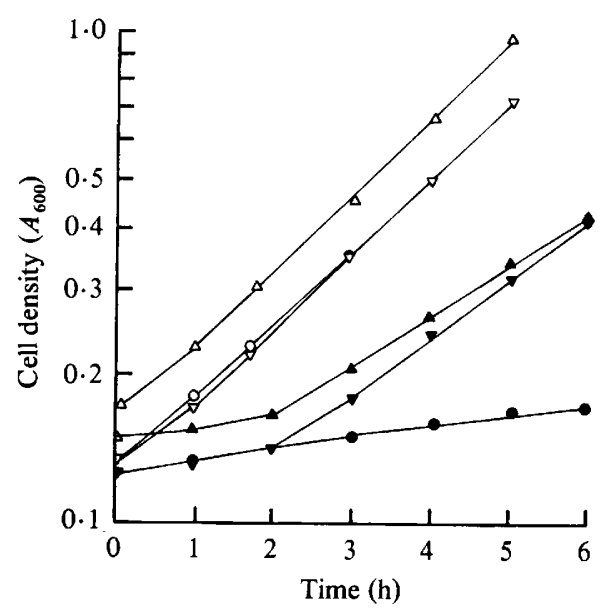

Fig. 1. Effects of 5-thioglucose on the adaptation of gluconate-grown strain HK 727 (iex) to growth on maltose $(\triangle, \Delta)$, lactose $(\nabla, \nabla)$ and fructose $(O, \bigcirc)$. The growth of cultures in the absence of 5thioglucose is indicated by open symbols; that in its presence, by solid symbols.

mutation does not alter the wild-type character of the relevant strain and that it readily utilizes both non-PT and PT sugars. In contrast, the gsr mutation, introduced into the pts $M$ genetic background, greatly impairs growth on glucose; growth on other carbon sources is, however, not affected. Moreover, since gsr pts $M$ mutants grow readily on glucose-6-phosphate, which is taken up without prior hydrolysis (Fraenkel et al., 1964; Winkler, 1966; Kornberg \& Smith, 1969), it must be the uptake of glucose and not its subsequent catabolism that is specifically affected by the $g s r$ mutation. As expected from the manner of their selection, gsr mutants are not inhibited by 5 -thioglucose during growth on fructose; since they are also not inhibited by this (and other) analogues of glucose on any other carbon source tested, it is likely that the lesion prevents entry of the analogues into the cells.

Although both the wild-type and iex strains are strongly inhibited by the presence of 5thioglucose (and other glucose analogues) in their ability to adapt to growth on PT sugars, iex mutants are less severely impaired by the analogue in their response to non-PT sugars than are wild-type cells (Fig. 1). This phenomenon is considered further in the last section of Results.

Competition between different sugars for uptake. It has long been established that glucose, added to wild-type cultures of $E$. coli that are utilizing either PT or non-PT sugars, inhibits the continued activity of the uptake systems for those other sugars: glucose is therefore subsequently taken up in preference (McGinnis \& Paigen, 1969, 1973; Kornberg, 1972, 1973). This 


\title{
Table 2. Rates of growth of iex and gsr mutants on various carbon sources
}

Inocula were grown at $30^{\circ} \mathrm{C}$ on gluconate, harvested, and adapted to growth at $30^{\circ} \mathrm{C}$ on hexoses at $10 \mathrm{~mm}$ and on disaccharides at $5 \mathrm{mM}$. Where indicated, 5-thioglucose (TG) was added together with the carbon source, to a final concentration of $1 \mathrm{mM}$. All strains were $p t s M$ pts $I^{\text {ts }} u m g C$.

\begin{tabular}{|c|c|c|c|}
\hline \multirow[b]{2}{*}{ Carbon source } & \multicolumn{3}{|c|}{$\begin{array}{l}\text { Generation time } \\
\text { (to nearest } 5 \mathrm{~min} \text { ) }\end{array}$} \\
\hline & $\begin{array}{c}\text { HK } 724 \\
(+)\end{array}$ & $\begin{array}{l}\text { HK656 } \\
\quad(g s r)\end{array}$ & $\begin{array}{l}\text { HK } 727 \\
\quad(\text { iex })\end{array}$ \\
\hline Fructose & 90 & 95 & 95 \\
\hline Fructose + TG & $>600$ & 95 & $>600$ \\
\hline Glucose & 90 & 330 & 90 \\
\hline Glucose 6-phosphate & 85 & 90 & 90 \\
\hline Sorbitol & 108 & 100 & 100 \\
\hline Sorbitol + TG & $>600$ & 105 & $>600$ \\
\hline Lactose & 90 & 95 & 90 \\
\hline Lactose + TG & $>600$ & 100 & $*$ \\
\hline Maltose & 105 & 110 & 95 \\
\hline Maltose + TG & $>600$ & 120 & $*$ \\
\hline
\end{tabular}

\footnotetext{
* The initial inhibition of growth was gradually overcome: this is shown in Fig. 1 and discussed further in the last section of Results.
}

Table 3. Utilization of glucose in the presence of other sugars by iex and gsr mutants

\begin{abstract}
Cultures were grown overnight at $30^{\circ} \mathrm{C}$ on the sugars listed at $10 \mathrm{~mm}$. They were harvested and resuspended in duplicate flasks of growth medium containing those sugars at either $5 \mathrm{~mm}$ (monosaccharides) or $2.5 \mathrm{~mm}$ (disaccharides). When growth recommenced, unlabelled glucose to $5 \mathrm{~mm}$ and a trace amount of the relevant sugar, labelled with ${ }^{14} \mathrm{C}$, was added to one flask, and $5 \mathrm{~mm}-\left[{ }^{14} \mathrm{C}\right] \mathrm{glucose}$ to its duplicate. Samples were taken at intervals throughout the subsequent growth and analysed as described by Amaral \& Kornberg (1975). All strains were ptsM ptsI ${ }^{\text {ts }} u m g C$.
\end{abstract}

\begin{tabular}{|c|c|c|c|c|}
\hline \multirow[b]{2}{*}{ Carbon source } & \multirow[b]{2}{*}{ Strain } & \multicolumn{3}{|c|}{$\begin{array}{l}\text { Fraction of carbon }(\%) \\
\text { derived from glucose }\end{array}$} \\
\hline & & $\begin{array}{c}\text { HK724 } \\
(+)\end{array}$ & $\begin{array}{c}\text { HK656 } \\
\text { (gsr) }\end{array}$ & $\begin{array}{c}\text { HK } 727 \\
\quad(\text { iex })\end{array}$ \\
\hline Fructose & & 92 & 30 & 71 \\
\hline Sorbitol & & 96 & 33 & 73 \\
\hline$N$-Acetylglucosamine & & 88 & 33 & 70 \\
\hline Lactose & & 94 & 32 & 38 \\
\hline Maltose & & 96 & 30 & 36 \\
\hline
\end{tabular}

phenomenon is illustrated in Table 3. However, gsr strains do not show this effect: in pts $M^{+}$ strains, the glucose and the carbon source that was used for growth prior to the addition of glucose are used simultaneously and to an approximately equal extent (Kornberg \& Watts, 1979); in pts $M$ strains, the other sugar predominates. This applies irrespective of whether that other sugar is a PT or non-PT sugar and supports the view that the gsr mutation is associated with an impairment of glucose uptake.

That the gsr lesion affects the uptake specifically of glucose is shown in two ways. (a) Like glucose, $N$-acetylglucosamine strongly inhibits the continued utilization of other PT sugars, such as fructose: when this substance was added to a culture of a $g s r^{+} p t s M$ organism growing on fructose, $75 \%$ of the carbon subsequently incorporated into the cells was derived from $\mathrm{N}$ acetylglucosamine. This proportion was not decreased when the strain used was gsr ptsM although (Table 3) such a strain no longer uses glucose preferentially. (b) A second line of evidence arises from direct assay of the phosphoenolpyruvate-dependent phosphorylation of different sugars by suspensions of cells rendered permeable with toluene (Kornberg \& Reeves, $1972 a, b$ ). The various strains used are all derived from strain PA309 (Bachmann, 1972) which 
Table 4. Phosphotransferase activities of gsr and iex mutants rendered permeable with toluene

The overall ability of toluene-treated cultures, grown initially on $10 \mathrm{~mm}-N$-acetylglucosamine or $10 \mathrm{~mm}$ fructose, to effect the phosphoenolpyruvate-dependent phosphorylation of appropriate substrates (at $0.1 \mathrm{mM}$ ) was measured by the procedure of Kornberg \& Reeves (1972a). All strains were ptsM ptsI ${ }^{\text {ts }}$ umgC.

\begin{tabular}{|c|c|c|c|c|c|c|}
\hline \multirow[b]{2}{*}{ Strain } & \multirow[b]{2}{*}{$\begin{array}{l}\text { Relevant } \\
\text { genotype }\end{array}$} & \multirow[b]{2}{*}{$\begin{array}{l}\text { Carbon source } \\
\text { for growth }\end{array}$} & \multicolumn{4}{|c|}{$\begin{array}{c}\text { Rate of phosphorylation } \\
{\left[\text { nmol (mg dry mass) }{ }^{-1} \text { min }^{-1}\right]}\end{array}$} \\
\hline & & & Fructose & $\begin{array}{l}N \text {-Acetyl- } \\
\text { glucosamine }\end{array}$ & Glucose & $\begin{array}{c}\text { Methyl } \\
\alpha \text {-glucosid }\end{array}$ \\
\hline \multirow[t]{2}{*}{ HK 724} & + & $\begin{array}{l}\mathrm{N} \text {-Acetyl- } \\
\text { glucosamine }\end{array}$ & 10 & 90 & 95 & 90 \\
\hline & & Fructose & 90 & $<5$ & 110 & 90 \\
\hline \multirow[t]{2}{*}{ HK656 } & $g s r$ & $\begin{array}{l}N \text {-Acetyl- } \\
\text { glucosamine }\end{array}$ & 15 & 80 & 9 & 9 \\
\hline & & Fructose & 68 & $<5$ & 10 & 10 \\
\hline \multirow[t]{2}{*}{ HK 727} & iex & $\begin{array}{l}N \text {-Acetyl- } \\
\text { glucosamine }\end{array}$ & 15 & 90 & 95 & 88 \\
\hline & & Fructose & 77 & $<5$ & 121 & 118 \\
\hline
\end{tabular}

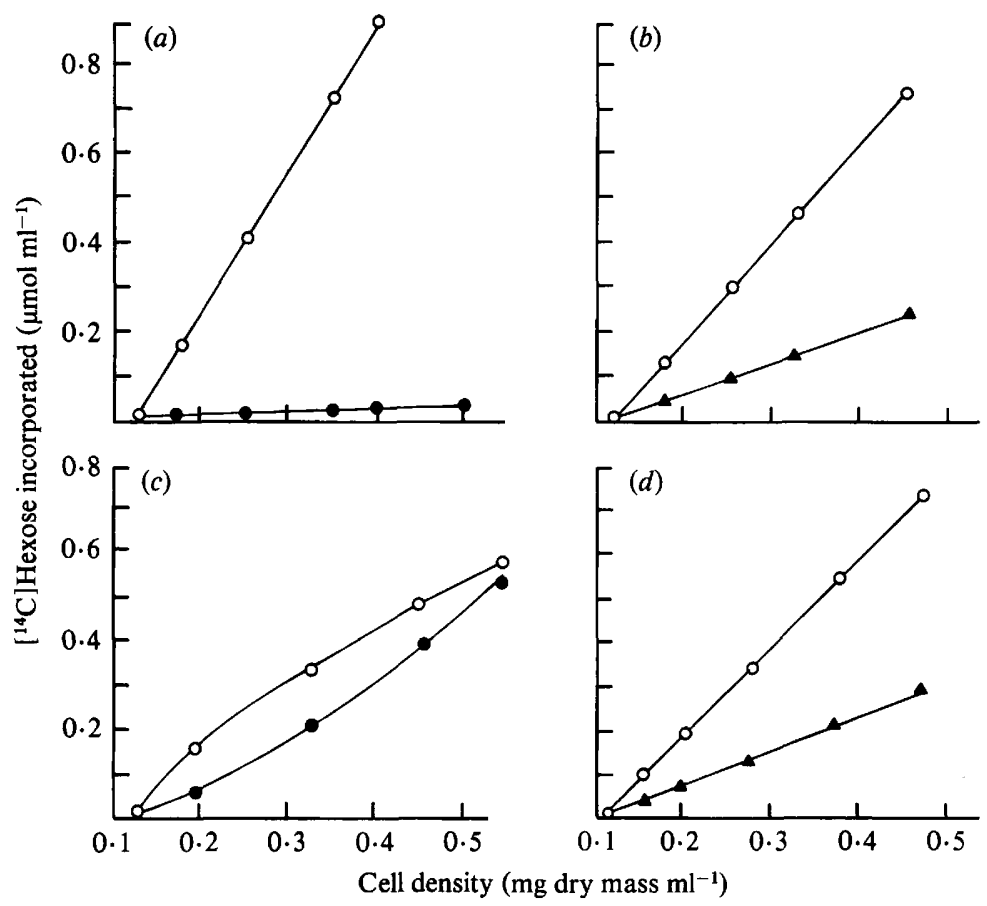

Fig. 2. Relative utilization of lactose $(O)$ and glucose $(O)$, and fructose $(\boldsymbol{\Delta})$ and glucose $(O)$, during growth of iex ${ }^{+}$and iex mutants of $E$. coli. $(a, b)$ Experiments with strain HK $724\left(i e x^{+}\right),(c, d)$ experiments with strain HK727 (iex). All inocula were grown on fructose overnight.

expresses the activity of the principal enzyme II for the uptake of glucose and of methyl $\alpha$ glucoside constitutively (umgC; Kornberg \& Reeves, 1972a); this makes it possible to compare the activity of that component of the phosphotransferase system even though the cultures were grown on fructose or $N$-acetylglucosamine as sole carbon source. It is apparent from Table 4 that gsr mutants phosphorylate $0.1 \mathrm{~mm}$-glucose or $0.1 \mathrm{mM}$-methyl $\alpha$-glucoside much less readily than do either wild-type or iex strains; however, no such differences are observed in the phosphorylation of $0.1 \mathrm{mM}$-fructose or $0.1 \mathrm{mM}-N$-acetylglucosamine.

In contrast to these findings with gsr strains, Table 3 shows that, in the iex strain HK727, 
Table 5. Dominance of the wild-type allele $\mathrm{gsr}^{+}$in the utilization of glucose and of $\mathrm{N}$-acetylglucosamine preferentially to fructose, and the activity of adenylate cyclase

\begin{tabular}{|c|c|c|c|c|c|}
\hline \multirow[b]{2}{*}{ Strain } & \multirow[b]{2}{*}{$\begin{array}{l}\text { Relevant } \\
\text { genotype }\end{array}$} & \multicolumn{2}{|c|}{$\begin{array}{c}\text { Fraction of carbon }(\%) \text { derived } \\
\text { from fructose by cells } \\
\text { growing on fructose plus: }\end{array}$} & \multicolumn{2}{|c|}{$\begin{array}{l}\text { Adenylate cyclase activity } \\
\left.\text { [pmol } \mathrm{min}^{-1}(\mathrm{mg} \text { protein })^{-1}\right] \\
\text { in gluconate-grown cells } \\
\text { in the presence of: }\end{array}$} \\
\hline & & Glucose & $\overbrace{N \text {-Acetylglucosamine }}$ & $\begin{array}{l}\text { No } \\
\text { addition }\end{array}$ & $\begin{array}{c}0 \cdot 1 \text { mM-Methyl } \\
\alpha \text {-glucoside }\end{array}$ \\
\hline JM1784 & $g s r^{+}$ & 17 & 25 & 23 & $2 \cdot 3$ \\
\hline JM1781 & gsr & 63 & 20 & $1 \cdot 5$ & 0.6 \\
\hline JM1785 & $g s r / \lambda g s r^{+}$ & 26 & 23 & 11 & $0 \cdot 2$ \\
\hline
\end{tabular}

glucose was still used preferentially to the PT sugars fructose, sorbitol and $N$-acetylglucosamine: glucose had lost its ability to compete successfully with other sugars only when these other sugars were taken up by 'active transport', as is the case with lactose and maltose. This difference is graphically demonstrated also by Fig. 2, in which the competition between glucose and lactose, and glucose and fructose, was measured when fructose-grown cultures of strains HK 724 (iex $\left.{ }^{+}\right)$ and HK 727 (iex) were placed in media containing $5 \mathrm{~mm}$-glucose and either $2.5 \mathrm{~mm}$-lactose or 5 mM-fructose. The well-known exclusion of lactose by glucose (Monod, 1942) is exhibited by the iex ${ }^{+}$strain but not by its iex mutant; however, in both cultures, glucose still largely excludes fructose. Similarly, the iex mutant differs from the gsr mutant HK656 in that it is not impaired in phosphotransferase activity with either glucose or methyl $\alpha$-glucoside as substrate (Table 4).

Adenylate cyclase activity. The adenylate cyclase activity of all $g s r$ mutants of $E$. coli that have been investigated is considerably lower than that of either wild-type strains or iex mutants (Kornberg \& Watts, 1978, 1979; Kornberg et al., 1980; Kornberg, 1981); there were no significant differences between wild-type strains and iex mutants in this activity. This strongly suggests that the gsr lesion affects a component of the phosphotransferase system that not only specifically impairs the uptake and phosphorylation of glucose and of methyl $\alpha$-glucoside but that also plays a role in the activation of adenylate cyclase.

\section{Dominance of wild-type alleles $g s r^{+}$and iex ${ }^{+}$}

To obtain a better understanding of the lesions in gsr and iex mutants, heterozygous diploids were constructed by infecting the $c y s A$ gsr mutant JM1781 with a hybrid lambda phage ( $\lambda$ JM28) that carried E. coli DNA containing the $g s r^{+}$allele; two Cys ${ }^{+}$progeny strains JM1784 $\left(c y s^{+} g s r^{+}\right)$ and JM1785 (cys gsr $/ \lambda$ cys $^{+}$gsr $^{+}$) were obtained. Measurement of the proportion of carbon derived from fructose when the three strains were grown on mixtures of fructose and either glucose or $\mathrm{N}$-acetylglucosamine showed that the ability of glucose to exclude fructose was largely restored in the partial diploid (Table 5); the preference for $\mathrm{N}$-acetylglucosamine over fructose was not affected by the nature of the $g s r$ allele present. Furthermore, the activity of adenylate cyclase, which in the gsr mutant was only about $7 \%$ of that found in the $g s r^{+}$strain, was greatly raised in the $g s r^{+} / g s r$ diploid. This not only shows that the wild-type allele of $g s r$ is dominant but supports the view that the $g s r^{+}$allele specifies one component of the phosphotransferase system involved both in the uptake of (specifically) glucose and in the activation of adenylate cyclase.

In an analogous manner, the iex/ $/$ iex $^{+}$diploid strain FP19 was constructed by lysogenizing a $p t s H$ mutant with the lambda phage $\lambda \mathrm{JM} 29$ that carries $E$. coli DNA including the $p t s H^{+}$and $i^{+}$alleles. This diploid strain resembled the wild-type in that glucose and $\mathrm{N}$-acetylglucosamine were used in marked preference to lactose (Table 6). However, since lactose competed effectively with either of these PT sugars in iex strains, the effect of the iex $x^{+}$allele was dominant. These results confirm those shown in Table 3, that the effect was not glucose-specific. It is also evident that the nature of the iex allele present exerted no significant effect on the activity of adenylate cyclase. 
Table 6. Dominance of the wild-type allele iex ${ }^{+}$in the utilization of glucose and of $N$-acetylglucosamine preferentially to lactose, and the activity of adenylate cyclase

For measurements of relative utilization of carbohydrates, cells were grown overnight on either glucose or $\mathrm{N}$-acetylglucosamine. Cultures were resuspended in media containing these substrates $(5 \mathrm{mM})$; when growth recommenced, $2.5 \mathrm{~mm}-\left[{ }^{14} \mathrm{C}\right]$ lactose was added. For adenylate cyclase assay, cultures were grown in sorbitol: this stabilized the $p t s H / p t s H^{+}$diploid FP19.

\begin{tabular}{|c|c|c|c|c|c|}
\hline \multirow[b]{2}{*}{ Strain } & \multirow[b]{2}{*}{$\begin{array}{l}\text { Relevant } \\
\text { genotype }\end{array}$} & \multicolumn{2}{|c|}{$\begin{array}{l}\text { Fraction of carbon }(\%) \text { derived } \\
\text { from lactose by cells } \\
\text { growing on }\left[{ }^{14} \mathrm{C}\right] \text { lactose plus: }\end{array}$} & \multicolumn{2}{|c|}{$\begin{array}{l}\text { [pmol } \min ^{-1}(\mathrm{mg} \text { protein })^{-1} \\
\text { in sorbitol-grown cells } \\
\text { in the presence of: }\end{array}$} \\
\hline & & Glucose & $\mathrm{N}_{N \text {-Acetylglucosamine }}$ & $\begin{array}{c}\text { No } \\
\text { addition }\end{array}$ & $\begin{array}{c}0.1 \text { mM-Methyl } \\
\alpha \text {-glucoside }\end{array}$ \\
\hline FP31 & $i e x^{+}$ & 3 & 7 & $3 \cdot 1$ & $<0 \cdot 1$ \\
\hline FP6 & iex & 46 & 56 & $3 \cdot 7$ & $<0.1$ \\
\hline FP19 & $\begin{array}{l}\text { ptsH iexl } \\
\lambda p t s H^{+} i e x^{+}\end{array}$ & 9 & 17 & $4 \cdot 4$ & $<0 \cdot 1$ \\
\hline
\end{tabular}

The role of the iex gene product in inducer exclusion

The inhibitory action of glucose on the continued utilization of non-PT sugars is complex and involves at least two components. Glucose may not only serve (i) to inhibit the induction of necessary enzymes, by catabolite repression (which also involves the inhibition of adenylate cyclase and hence gsr gene function), but may (ii) inhibit the penetration of those first molecules of substrate that are needed to initiate the induction process: it is this latter effect of glucose that is termed 'inducer exclusion'. A further complication may be introduced when noncatabolizable analogues of glucose are used to study these processes: these analogues may accumulate, as their phosphate esters, and in consequence inhibit growth (reviewed by Ferenci \& Kornberg, 1974).

Adaptation to new carbon sources. Experiments on the effects of glucose and its analogues methyl $\alpha$-glucoside and 5-thioglucose on the adaptation of iex $x^{+}$and iex mutants to new carbon sources illustrates all these features and provide an insight into the role of the iex gene product. These experiments may be summarized as follows. (a) The adaptation to growth on non-PT sugars, such as maltose or lactose, by gluconate-grown $i e x^{+}$mutants is strongly inhibited by methyl $\alpha$-glucoside or 5-thioglucose. No significant growth of strain HK724 (ptsIts ptsM) occurred at $30^{\circ} \mathrm{C}$ over $8 \mathrm{~h}$, although cultures from which the glucose analogues had been omitted had grown for more than three cell doublings in that time. However, (b) when this experiment was repeated with cells that had been grown initially on maltose or lactose, the inhibitory effect of the glucose analogues on the culture now placed in medium containing the same sugar was short-lived: after a lag of $2-3 \mathrm{~h}$, the cells grew almost as rapidly on maltose +5 -thioglucose, or lactose +5 -thioglucose, as they did on the non-PT sugars alone. (c) Gluconate-grown cultures of iex strains grew, after a short lag, on maltose or lactose even though $1 \mathrm{~mm}-5$-thioglucose was present: they thus behaved like pre-induced iex ${ }^{+}$strains (Fig. 1). (d) iex strains pre-induced by overnight growth on maltose or lactose continued to grow on these substrates, at rates not significantly diminished by addition of 5-thioglucose or methyl $\alpha$-glucoside. In contrast, neither iex ${ }^{+}$nor iex strains adapted to growth on PT sugars when the glucose analogues were present, even when the cells had been pregrown on those sugars.

Inhibition of transport. The above observations suggest that 'inducer exclusion' by glucose analogues is effective to only a limited extent and can be overcome by altering the relative proportions of induced permease and the product of the iex ${ }^{+}$gene: this latter would, of course, be absent from iex strains. This view is supported by direct measurement of the effectiveness of methyl $\alpha$-glucoside as an inhibitor of permease function. In these experiments, $\beta$-galactoside permease was induced by IPTG gratuitously and progressively for various lengths of time, and the activity of that permease was measured in the presence of a great excess $(5 \mathrm{mM})$ of methyl $\alpha$ glucoside and in its absence (Table 7). When only little permease activity had been induced, the inhibition by methyl $\alpha$-glucoside was virtually complete (Fig. 3). However, methyl $\alpha$-glucoside 
Table 7. Effect of methyl $\alpha$-glucoside on the activity of $\beta$-galactoside permease

Cells were grown overnight in medium containing lactate as sole carbon source. After initiation of growth in fresh lactate-containing medium, inducer (1 mM-IPTG) was added. After different times of induction, cells were harvested, washed and resuspended in $50 \mathrm{~mm}$-sodium phosphate buffer, pH 7·2, containing $125 \mu \mathrm{g}$ chloramphenicol $\mathrm{ml}^{-1}$, for determination of the $\beta$-galactoside permease activity. Permease activities are expressed as the amounts (nmol) of ONPG hydrolysed by whole cells (mg dry mass) $)^{-1} \min ^{-1}$ at $30^{\circ} \mathrm{C}$.

$\begin{array}{lcccc}\text { Strain } & \begin{array}{c}\text { Relevant } \\ \text { genotype }\end{array} & \begin{array}{c}\text { Time of } \\ \text { induction } \\ \text { (min) }\end{array} & \begin{array}{c}\text { Permease } \\ \text { activity }\end{array} & \begin{array}{c}\text { Inhibition }(\%) \text { of ONPG } \\ \text { hydrolysis by } 5 \text { mM- } \\ \text { methyl } \alpha \text {-glucoside }\end{array} \\ \text { FP31 } & \text { iex }{ }^{+} & 10 & 15 & 30 \\ & 20 & 36 & 11 \\ \text { FP20 } & 30 & 50 & 10 \\ & \text { iex } & 10 & 18 & <5 \\ & & 30 & 40 & <5 \\ & 30 & 57 & <5\end{array}$

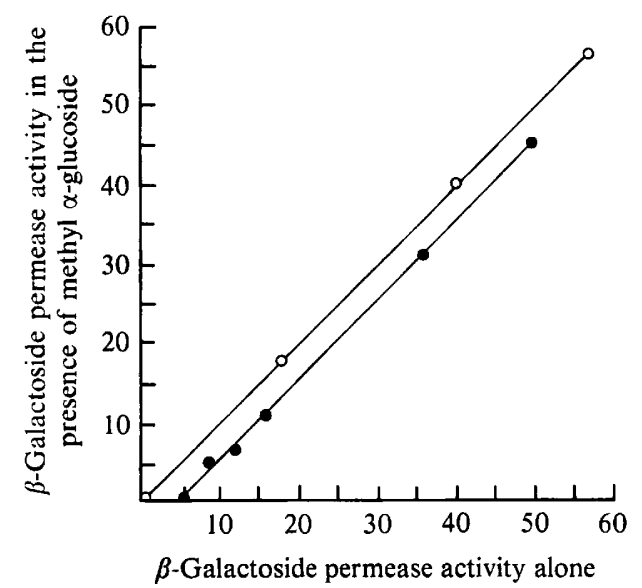

Fig. 3. Effect of $5 \mathrm{mM}$-methyl $\alpha$-glucoside on the activity of $\beta$-galactoside permease by iex (O) and iex $x^{+}$ (O) strains of $E$. coli, induced by exposure to IPTG for various lengths of time.

was only marginally effective as an inhibitor of the much greater activities of permease formed by the cells after more prolonged exposure to IPTG. This effect was not due to the metabolism of galactose, derived from the hydrolysis of ONPG used in the assay, since a galK mutant behaved identically. These observations confirm those of Koch (1971), who used a lactose-constitutive strain grown on glucose, of Kalachev et al. (1981), and of Postma (1982).

In contrast, the permease activity induced in iex strains in this manner was not inhibited by methyl $\alpha$-glucoside at any level: this indicates that the ie $x^{+}$gene product is directly involved in this effect. This is also indicated by the more detailed time-course of an experiment of this type (Fig. 3), in which the permease activity of each sample of cells after induction with IPTG, measured in the presence of methyl $\alpha$-glucoside, is plotted against the activity of the same sample measured in its absence. With iex strains, where no inhibition is observed, the slope of the line relating these two rates is unity and passes through the origin; with iex $x^{+}$strains, where inhibition is observed, the slope is identical but the intercept on the abscissa is displaced.

Two other observations suggest an interaction of the permease with a limited amount of iex $x^{+}$ gene product. If another transport system, such as that for maltose, which is also subject to regulation by the iex gene, was first induced (for example, by overnight growth of the cells on that sugar), the $\beta$-galactoside permease activity subsequently induced by IPTG was much less 
Table 8. Effect of growth substrate on the inhibition of $\beta$-galactoside permease activity by methyl $\alpha$-glucoside

Cells were grown overnight in either lactate or maltose and resuspended in fresh medium of the same type; $\beta$-galactoside permease was induced by addition of $1 \mathrm{mM}$-IPTG. The subsequent operations were as described for Table 7.

$\begin{array}{ccccc}\text { Strain } & \begin{array}{c}\text { Time of } \\ \text { induction } \\ (\mathrm{min})\end{array} & \begin{array}{c}\text { Permease } \\ \text { activity }\end{array} & \overbrace{\text { Maltose }}^{\text {Lactate }} \\ \text { FP31 }\left(\text { ie } x^{+}\right) & 5 & 8 \cdot 1 & 29 & 60 \\ \text { by cells grown on : } & 17 & 16 & 32\end{array}$

Table 9. Factors affecting the utilization of mixtures of glucose and lactose

Cells were grown overnight in media containing the carbon source, and inducer where appropriate, listed below. They were harvested and resuspended in duplicate flasks containing $2.5 \mathrm{mM}-\left[{ }^{14} \mathrm{C}\right]$ lactose and $5 \mathrm{~mm}$-glucose, and $2.5 \mathrm{~mm}$-lactose and $5 \mathrm{~mm}-\left[{ }^{14} \mathrm{C}\right]$ glucose. The relative utilization of these sugars was measured over 3-4 cell doublings, as described by Amaral \& Kornberg (1975).

\begin{tabular}{|c|c|c|c|}
\hline Strain & $\begin{array}{l}\text { Relevant } \\
\text { genotype }\end{array}$ & $\begin{array}{l}\text { Carbon source and inducer } \\
\text { in overnight culture used } \\
\text { for experiment }\end{array}$ & $\begin{array}{l}\text { Fraction of carbon }(\%) \text { derived } \\
\text { from glucose by cells } \\
\text { growing on } 2.5 \text { mM-lactose } \\
\text { and } 5 \mathrm{~mm} \text {-glucose }\end{array}$ \\
\hline FP31 & $i e x^{+}$ & $\begin{array}{l}\text { Glucose } \\
\text { Lactose } \\
\text { Glycerol + } \\
1 \text { mM-IPTG }\end{array}$ & $\begin{array}{l}97 \\
77 \\
50\end{array}$ \\
\hline FP34 & $i e x+\operatorname{Lac}^{\mathfrak{c}}$ & Glycerol & 43 \\
\hline FP20 & $i e x$ & Glucose & 50 \\
\hline
\end{tabular}

sensitive to inhibition by methyl $\alpha$-glucoside than it was in cells grown on e.g. lactate, whose transport does not involve iex gene function (Table 8). Secondly, the relative utilization of lactose in the presence of glucose, which in $i e x^{+}$strains pre-grown on glucose is virtually nil (Fig. 2 ), could be greatly increased in two ways: (i) by prior induction of $\beta$-galactoside permease, either through growth on lactose or, more effectively, by growth in the presence of IPTG; and (ii) by mutation to constitutivity of the lac operon. When the $\beta$-galactoside permease was fully induced, glucose and lactose were utilized simultaneously and to an equal extent (Table 9). The same rate of uptake of these two sugars could also be obtained, even in cells pre-grown on glucose, when the strain used was iex.

These results can all be explained if the iex $x^{+}$gene specifies an inhibitor of transport that is made in limiting amounts, so that it can be titrated out by inducing any of the permeases with which it interacts.

\section{DISCUSSION}

The recognition that $E$. coli contains two regulatory genes, designated gsr and iex, that are clearly distinguishable both by the different phenotypes of gsr and iex mutants and by their location on the E. coli genome (Kornberg \& Watts, 1979; Britton et al., 1983), appears to be in conflict with earlier work on $S$. typhimurium and with the models for the mechanisms of catabolite repression and inducer exclusion derived from them. This apparent conflict may have a simple explanation: the gsr and iex genes in $S$. typhimurium may lie in so close a proximity that some or all 'crr' mutants of that organism may be double mutants. There are good grounds for 
this belief. The crr mutants of $S$. typhimurium that have been described (Saier \& Roseman, 1972) appear to fall into at least three classes, the properties of some of which reflect gsr iex ${ }^{+}$and gsr iex mutants in $E$. coli. Detailed genetic analysis of the gene order adjacent to the markers that specify enzyme I and HPr on the Salmonella chromosome (Cordaro \& Roseman, 1972) revealed a sequence:

$$
\text { crr } \cdot \text { ptsI } \cdot \text { pts } H \cdot c y s K
$$

In contrast, the gene order in $E$. coli, confirmed by restriction endonuclease analysis of cloned genes (Britton et al., 1983), is

$$
\text { cys } A \cdot g s r \cdot p t s I \cdot p t s H \cdot i e x \cdot c y s Z \cdot l i g
$$

Although no direct evidence is yet available on the nature of the mutations in $S$. typhimurium, it is likely that the manner in which 'crr' mutants were selected favoured the emergence of organisms affected in more than one property. The basis of such selection lay in the observation that mutants impaired in, but not totally devoid of, enzyme I activity were still capable of inducing the permeases for non-PT sugars but that this induction was unusually sensitive to inhibition by methyl $\alpha$-glucoside. Further mutants that were no longer inhibited by the glucose analogue were described as being 'carbohydrate repression resistant', the initial letters of which phrase formed the acronym used also for defining the relevant gene. One effective way in which inhibition by methyl $\alpha$-glucoside can be overcome is to inactivate a component of the PT system specifically involved in the uptake of that glucose analogue and, indeed, 'crr' mutants of $S$. typhimurium have been shown to be deficient in the factor IIIGlc (Saier \& Roseman, 1976). Such mutants correspond to the gsr mutants of $E$. coli and, as expected, are also impaired in adenylate cyclase activity. It is possible that other 'crr' mutants of $S$. typhimurium, that are not greatly impaired in adenylate cyclase activity, may be of a type corresponding to the iex mutants of $E$. coli that are described in the present paper.

The recognition that, in $E$. coli there are two genes, gsr and iex, that specify distinct and separate regulatory properties makes it necessary to modify models that have been put forward for the role of the PT system in catabolite repression and inducer exclusion. One such model was proposed by Saier \& Feucht (1975) and has been frequently reviewed (Saier \& Stiles, 1975; Postma \& Roseman, 1976; Osumi \& Saier, 1982). Its central feature is that a regulatory protein RPr was postulated to exist which could control the activity of non-PT sugar permeases by binding to them at allosteric regulatory sites. The passage of phosphate from phosphoenolpyruvate to $\mathrm{RPr}$, via enzyme I and $\mathrm{HPr}$, would phosphorylate it: this phosphorylation to $\mathrm{P}-\mathrm{RPr}$ would prevent binding to the allosteric site. On the basis of genetical evidence obtained with mutants of $S$. typhimurium, and of measurements of the binding of factor III ${ }^{\mathrm{Glc}}$ (purified from Salmonella) to $E$. coli membranes rich in $\beta$-galactoside permease, in the presence of enzyme I, HPr and phosphoenolpyruvate, Osumi \& Saier (1982) concluded that the regulatory protein RPr is identical with factor III ${ }^{\text {Glc }}$. This model would not, however, explain the phenotype of iex mutants of $E$. coli, that are unimpaired in the uptake of methyl $\alpha$-glucoside and of glucose, and in adenylate cyclase activity (which are determined by factor III $^{\mathrm{Glc}}$ ), but in which lactose is excluded neither by glucose nor by $N$-acetylglucosamine. It would also not explain the finding that $g s r$ mutants, that contain greatly diminished amounts of factor III ${ }^{\mathrm{Glc}}$, retain inducer exclusion' for all effective substances (like $N$-acetylglucosamine and gluconate) save glucose. We therefore postulate a modified model in which the function of the gsr gene product, which probably is factor IIIGle, is (i) to interact with the PtsG system in the membrane to effect the uptake of most of the glucose, and all of the methyl $\alpha$-glucoside, that may be present in the medium, and (ii) to interact with the adenylate cyclase in the membrane in order to modulate its activity. The function of the iex gene product, on the other hand, is to modulate the activity of permeases for non-PT sugars, possibly in a manner analogous to that postulated for RPr.

The division of function between the gsr gene, which specifies glucose-specific repression, and iex which specifies inducer exclusion, would make it possible to resolve present confusion in the literature by an appropriate change in nomenclature. Thus, 'crr' in $S$. typhimurium, which has been termed tgs in $E$. coli, could become $g s r$, whereas the gene previously designated $c r r$ in $E$. coli could become iex. We shall continue to use this nomenclature henceforth. 
We thank Mrs Kathleen Brown and Miss Elizabeth Bliss for technical assistance, and The Science and Engineering Research Council for support under Grant GR/B/2248.2. This work was done while F.P. held an EMBO Research Fellowship.

\section{REFERENCES}

Amaral, D. \& Kornberg, H. L. (1975). Regulation of fructose uptake by glucose in Escherichia coli. Journal of General Microbiology 90, 157-168.

Ashworth, J. M. \& Kornberg, H. L. (1966). The anaplerotic fixation of carbon dioxide by Escherichia coli. Proceedings of the Royal Society of London B165, 179-188.

BachmanN, B. J. (1972). Pedigrees of some mutant strains of Escherichia coli K12. Bacteriological Reviews 36, 525-557.

Berman, M., Zwaig, N. \& Lin, E. C. C. (1970). Suppression of a pleiotropic mutant affecting glycerol dissimilation. Biochemical and Biophysical Research Communications 38, 272-275.

Britton, P., Boronat, A., Hartley, D. A., JonesMortimer, M. C., Kornberg, H. L. \& Parra, F. (1983). Phosphotransferase-mediated regulation of carbohydrate utilisation in Escherichia coli K12: location of the gsr (tgs) and iex (crr) genes by specialized transduction. Journal of General Microbiology 129, 349-358.

Cordaro, J. C. \& Roseman, S. (1972). Deletion mapping of the genes coding for HPr and enzyme I of the phosphoenolpyruvate: sugar phosphotransferase system in Salmonella typhimurium. Journal of Bacteriology 112, 17-29.

Curtis, S. J. \& Epstein, W. (1975). Phosphorylation of D-glucose in Escherichia coli mutants defective in glucosephosphotransferase, mannosephosphotransferase and glucokinase. Journal of Bacteriology 122, 1189-1199.

FERENCI, T. \& KorNBERG, H. L. (1974). The utilisation of fructose by Escherichia coli: properties of a mutant defective in fructose 1-phosphate kinase activity. Biochemical Journal 132, 341-347.

Fraenkel, D. G., Falcoz-Kelly, F. \& Horecker, B. L. (1964). The utilisation of glucose-6-phosphate by glucokinaseless and wild-type strains of $E$. coli. Proceedings of the National Academy of Sciences of the United States of America 52, 1207-1313.

GERSHANOVITCH, V. N., BOURD, G. I., JUROVITZKAYA, N. V., SKavronskaya, A. G., KlyUtchova, V. V. \& ShabolenKo, V. P. (1967). $\beta$-Galactosidase induction in cells of Escherichia coli not utilising glucose. Biochimica et biophysica acta 134, 188-190.

GerShaNOVITCH, V. N., ILYINA, T. S., RuSina, O. Y., Yourovitskaya, N. V. \& Bolshakova, T. N. (1977). Repression of inducible enzyme synthesis in a mutant of Escherichia coli $\mathrm{K} 12$ deleted for the $\mathrm{ptsH}$ gene. Molecular and General Genetics 153, 185-190.

JONES-MORTIMER, M. C. \& KoRNBERG, H. L. (1974). Genetic control of inducer exclusion by Escherichia coli. FEBS Letters 48, 93-95.

Kalachev, I. Ya., Umyaroz, A. M. \& Bourd, G. I. (1981). Interaction of membrane transport proteins in E. coli K12. Biokhimiya 46, 732-743 (Russian); 611-620 (English).

KoCH, A. L. (1971). Local and non-local interactions of fluxes mediated by the glucose and galactose permeases of Escherichia coli. Biochimica et biophysica acta 249, 197-215.

KORNBERG, H. L. (1972). Nature and regulation of hexose uptake by Escherichia coli. In The Molecular Basis of Biological Transport, Miami Winter Symposia, vol. 3, pp. 157-180. Edited by J. F. Woessner \& F. Huijing. London: Academic Press.

KORNBERG, H. L. (1973). Fine control of sugar uptake by Escherichia coli. Symposia of the Society for Experimental Biology 27, 175-193.

KORNBERG, H. L. (1981). Formation and utilisation of PEP in microbial carbohydrate transport. Current Topics in Cellular Regulation 18, 313-327.

KORNBERG, H. L. \& JONES-MORTIMER, M. C. (1975). pts $X$ : a gene involved in the uptake of glucose and fructose by Escherichia coli. FEBS Letters 51, 1-4.

KorNBERG, H. L. \& ReEves, R. E. (1972a). Correlation between hexose transport and phosphotransferase activity in Escherichia coli. Biochemical Journal 126, 1241-1243.

KoRnBERG, H. L. \& ReEves, R. E. (1972b). Inducible phosphoenolpyruvate-dependent hexose phosphotransferase activities in Escherichia coli. Biochemical Journal 128, 1339-1344.

KORNBERG, H. L. \& SMITH, J. (1969). Genetic control of hexose phosphate uptake by Escherichia coli. Nature, London 223, 1261-1262.

KORNBERG, H. L. \& WATTS, P. D. (1978). Roles of the crr-gene products in regulating carbohydrate uptake by Escherichia coli. FEBS Letters 89, 329-332.

KoRnBERG, H. L. \& WATTS, P. D. (1979). tgs and crr: genes involved in catabolite inhibition and inducer exclusion in Escherichia coli. FEBS Letters 104, 313316.

Kornberg, H. L., WatTS, P. D. \& Brown, K. (1980). Mechanisms of inducer exclusion by glucose. FEBS Letters 117, K28-K 36.

Kundig, W., Ghosh, S. \& Roseman, S. (1964). Phosphate bound to histidine in a protein as an intermediate in a novel phosphotransferase system. Proceedings of the National Academy of Sciences of the United States of America 52, 1067-1074.

MagasaniK, B. (1961). Catabolite repression. Cold Spring Harbor Symposia on Quantitative Biology 26, 249-256.

McGinnis, J. F. \& Paigen, K. (1969). Catabolite inhibition: a general phenomenon in the control of carbohydrate utilisation. Journal of Bacteriology 100 , 902-913.

MCGinnis, J. F. \& Paigen, K. (1973). Site of catabolite inhibition of carbohydrate metabolism. Journal of Bacteriology 114, 885-887.

MonoD, J. (1942). Recherches sur la Croissance des Cultures Bactériennes. Paris: Hermann et Cie.

OsUmI, T. \& SAIER, M. H. (1982). Regulation of lactose permease activity by the phosphoenolpyruvate: sugar phosphotransferase system: evidence for direct binding of the glucose-specific enzyme III to the lactose permease. Proceedings of the National Acad- 
emy of Sciences of the United States of America 79, 1457-1461.

Pastan, I. \& Perlman, R. L. (1969). Repression of $\beta$ galactosidase synthesis by glucose in phosphotransferase mutants of Escherichia coli. Repression in the absence of glucose phosphorylation. Journal of Biological Chemistry 244, 5836-5842.

Postma, P. W. (1982). Regulation of sugar transport in Salmonella typhimurium. Annales de Microbiologie 133A, 261-267.

Postma, P. W. \& Roseman, S. (1976). The bacterial phosphoenolpyruvate: sugar phosphotransferase system. Biochimica et biophysica acta 457, 213-257.

Rickenberg, H. V., Cohen, G. N., Butrin, G. \& MoNOD, J. (1956). La galactoside-perméase d'Escherichia coli. Annales de l'Institut Pasteur 91, 829-857.

Roseman, S. (1972). A bacterial phosphotransferase system and its role in sugar transport. In The Molecular Basis of Sugar Transport, Miami Winter Symposia, vol. 3, pp 181-215. Edited by J. F. Woessner \& F. Huijing. London: Academic Press.

SAIER, M. H. \& FEUCHT, B. U. (1975). Coordinate regulation of adenylate cyclase and carbohydrate permeases by the phosphoenolpyruvate: sugar phosphotransferase in Salmonella typhimurium. Journal of Biological Chemistry 250, 7078-7080.

SAIER, M. H. \& Roseman, S. (1972). Inducer exclusion and repression of enzyme synthesis in mutants of Salmonella typhimurium defective in enzyme I of the phosphoenolpyruvate: sugar phosphotransferase system. Journal of Biological Chemistry 247, 972-975.

SAIER, M. H. \& Roseman, S. (1976). Sugar transport. The crr mutation: its effect on the repression of enzyme synthesis. Journal of Biological Chemistry 251, 6598-6605.

SAIER, M. H. \& STIles, C. D. (1975). Regulation of bacterial metabolism. In Molecular Dynamics in Biological Membranes, pp. 99-105. (Heidelberg Science Library). Berlin: Springer Verlag.

Salomon, Y., Londos, C. \& Rodbell, M. (1974). A highly sensitive adenylate cyclase assay. Analytical Biochemistry 58, 541-548.

Wang, R. J., Morse, H. G. \& Morse, M. L. (1970). Carbohydrate accumulation and metabolism in Escherichia coli: characteristics of the reversions of ctr mutations. Journal of Bacteriology 104, 13181324.

WATTS, P. D. (1979). Regulation of carbohydrate uptake by the phosphoenolpyruvate-dependent phosphotransferase system in Escherichia coli. Ph.D. thesis, University of Cambridge.

WAYGOOD, E. B. (1980). Resolution of the phosphoenolpyruvate: fructose phosphotransferase system of Escherichia coli into two components; enzyme II fructose and fructose-induced HPr-like protein (FPr). Canadian Journal of Biochemistry 58, 1144-1146.

WINKLER, H. H. (1966). A hexose-phosphate transport system in Escherichia coli. Biochimica et biophysica acta 117, 231-240. 